\title{
Rural development of regions of the Republic of Serbia in terms of employment and sources of income
}

\section{Рурални развој региона Републике Србије у погледу запослености и извора прихода}

\author{
Miloš Dimitrijević* \\ University of Kragujevac, Faculty of Economics, Kragujevac, Republic of Serbia, mdimitrijevic@kg.ac.rs \\ Lela Ristić \\ University of Kragujevac, Faculty of Economics, Kragujevac, Republic of Serbia, Iristic@kg.ac.rs \\ Danijela Despotović \\ University of Kragujevac, Faculty of Economics, Kragujevac, Republic of Serbia, ddespotovic@kg.ac.rs
}

\begin{abstract}
Integrated rural development enables linking agriculture with other economic activities whereby an adequate approach to regional development contributing to a more balanced development among regions. The aim of this research is to indicate that with the concept of integral rural development the differences between regions or rural and urban areas of Serbia could be reduced. Through the Kruskal-Wallis test for comparison of groups, the important differences were compared, where the results of research showed that they are very significant, especially between the Belgrade Region and the predominantly rural regions of Serbia. These differences can be overcome in rural areas if agriculture is more intensively linked with tertiary and secondary sectors.
\end{abstract}

Keywords: integrated rural development, regional development, rural and urban areas, regions, employed population and workers, income diversification

JEL classification: R11, R20, R50

Сажетак: Интегрални рурални развој омогућава повезивање пољопривреде са другим економским активностима, чиме адекватан приступ регионалном развоју доприноси уравнотеженијем развоју међу регионима. Циљ овог истраживања је да укаже на то да би се концептом интегралног руралног развоја могле смањити разлике између региона или руралних и урбаних подручја Републике Србије. KruskalWallis тестом за упоређивање група упоређиване су важне разлике, где су резултати истраживања показали да су веома значајне, посебно између Београдског региона и претежно руралних региона Републике Србије. Ове разлике могу се превазићи у руралним подручјима ако је пољопривреда интензивније повезана са терцијарним и секундарним секторима.

Кључне речи: интегрални рурални развој, регионални развој, рурална и урбана подручја, региони, запослено становништво и радници, диверзификација дохотка

JEЛ класификација: R11, R20, R50 


\section{Introduction}

Integrated rural development is a concept for a comprehensive approach to rural development (Leupolt, 1977). In addition to development of agriculture, it also implies development of other economic activities and non-economic sectors in rural areas. The diversification of rural economy is especially significant, through development of small and medium enterprises for processing agricultural products, as well as development of tourism in rural areas. It must be accompanied by development of rural infrastructure, public services, etc. Integral rural development offers a significant opportunity to reduce the enormous rural poverty. Heterogeneity of conditions under which the rural poor operate requires creativity in project implementation, and this has to be done locally through decentralization (De Janvry \& Sadoulet, 2005).

Globalization has a pervasive influence across rural Europe. The uneven geographies of globalization include differences between urban and rural areas, but also different outcomes between different rural regions. Implementation of rural development programmes is contingent on structural constraints and the serendipity of local agency, such that the outcomes of globalization will continue to be different in different rural regions (Woods \& McDonagh, 2011).

In the literature, it is often pointed out that the future of agrarian sector is strongly linked to the balanced development of rural areas. Accordingly, the EU reforms its agrarian policy into rural development policy by adopting the concept of integrated sustainable rural development, due to the need for a new approach to the development of economy and agriculture in rural areas. Harmonization with the EU rural development policy in the Republic of Serbia (EU candidate country) aims to enable more efficient connection of agriculture with other branches, in order to provide new jobs, more investment and exports from the Republic of Serbia. The Republic of Serbia has favourable natural conditions for agricultural and rural development, but the negative development trend is followed by deagrarianism and demographic emptying of villages. Because of that, new paradigm of sustainable agricultural and rural development, as well as new agricultural and rural policy is needed (Pejanović et al., 2017).

The subject of research in this paper are significant differences in the rural development of the regions of the Republic of Serbia. Accordingly, the aim of this research is to determine what are the most important differences in the development of rural areas of the Republic of Serbia, as well as what are the possibilities of overcoming the differences, through an integrated approach to rural development in the regions where such an approach can be applied. The example of Serbia could be useful for other countries with similar resources and limitations for development.

This paper assumes that the significant differences that exist between extremely rural regions and those that are not, that is, between income generated in rural and non-rural areas, could be largely overcome through the process of integrated rural development, i. e. integration agriculture with non-agricultural activities in rural areas. 


\section{Literature review}

Rural areas are of particular importance for many countries around the world, with different definitions of these areas. One of the most accepted definition of rural areas is the OECD typology, which is based on population density and size criteria (OECD, 2011). Namely, OECD methodology identifies predominantly urban, significantly rural and predominantly rural regions. Thereby, areas with a population density of less than 150 inhabitants per $\mathrm{km}^{2}$ have been classified as rural. According to the OECD methodology, rural areas occupy about $85 \%$ of the total territory of Serbia.

Rural development refers to the development of rural areas, where it is primarily focused on the development of agriculture and manufacturing SMEs, especially SMEs in food industry, then trade, tourism, crafts and infrastructure, and greater availability of public services. The process of rural development is primarily conditioned by internal factors (management of available resources; transfer of knowledge and appropriate technological solutions to the rural economy; volume of support for increasing the competitiveness of farmers and rural economy, etc.) as well as external factors such as climate change, global economic, financial and political factors, international integrations, etc. (Kvrgić \& Ristić, 2018).

Rural development research is about the processes that determine the uneven geographic distribution of population, industry, and returns to nonfarm economic activities. Nominal incomes and rents decline dramatically with distance from urban centres. This emphasized the need to do more than identify rural labour market signals and trends (Kilkenny, 2010). In the contemporary conditions, the concept of sustainable rural development is becoming more and more relevant, which represents the integration of rural and sustainable development policy, with respecting the ecological, economic and social dimension of development.

Agriculture plays an important role in the concept of sustainable rural development, as traditionally the most represented activity of the rural economy (Ristić, 2013). Agriculture is not the major source of rural livelihoods, if still an important part of it. This is demonstrated by the current level and the consistently rising share of non-farm income in total household revenues throughout the developing world. Many households in contemporary rural areas comprise productive members who are either part-time farmers or non-agricultural income earners. State of different sector in contributions to sustainable rural development is reflected in agroecological multifunctionality and non-farm income diversification (Amekawa, 2011). The multifunctionality of agriculture is an important factor in the diversification of activities in rural areas, in terms of possible contribution to employment, etc. (Ploeg et al., 2000). Rural nonfarm employment (RNFE) is especially important for rural households in developing countries (Reardon et al., 2007).

Countryside will most probably not undergo radical shifts, but it can be proposed that this countryside will be more diversified, more socially and economically active, and 
more attractive as the place of residence and of work. Even though agriculture will continue to fulfil an important economic function, the incomes of households will mainly originate from the activities in other sectors of economy (service, construction, energy), or from the businesses indirectly associated with agricultural production (food processing, agritourism, protection of nature and of cultural heritage). These processes imply an increase in entrepreneurship of rural inhabitants. One particularly vital role in the development of the rural areas will be played by the small entities functioning in the spheres of service and food production (Bański, 2018).

Specific forms of horizontal integration in the agricultural sector have become more important, so cooperative groups of agricultural producers as their form play an important role in the socio-economic development of agriculture and rural areas, both in more and less economically developed countries. Thereby, agricultural cooperatives have a significant role in the overall economic and social development by creating jobs, generating income to their members and reducing poverty in rural areas (Pawlak et al., 2019).

There are different levels of analysis of rural development, such as farms, households, local communities, regions, national or global economies (Knickel \& Renting, 2000). Regionalization is important for the implementation of the rural development concept in order to overcome territorial differences of development and to achieve more balanced regional development (Rikalović et al., 2017). Thus, rural development policy must be coherent with regional development policy. It must be pointed out that the public sector - mainly the local government - tends to be the main facilitator of local cooperation in all fields. In underdeveloped rural regions, the local government is also the main actor of regional and rural development (Perger, 2016).

Table 1: Population per $1 \mathrm{~km}^{2}$, by regions of the Republic of Serbia ${ }^{*}$

\begin{tabular}{lllllllll}
\hline & 2010 & 2011 & 2012 & 2013 & 2014 & 2015 & 2016 & 2017 \\
\hline Belgrade Region & 512 & 514 & 515 & 516 & 518 & 519 & 521 & 522 \\
\hline Vojvodina Region & 91 & 90 & 89 & 88 & 88 & 88 & 87 & 87 \\
\hline $\begin{array}{l}\text { Sumadija and } \\
\begin{array}{l}\text { Western Serbia } \\
\text { Region }\end{array}\end{array}$ & 77 & 76 & 76 & 76 & 75 & 74 & 74 & 73 \\
$\begin{array}{l}\text { Southern and Eastern } \\
\text { Serbia Region }\end{array}$ & 63 & 63 & 61 & 60 & 60 & 59 & 59 & 58 \\
\hline $\begin{array}{l}\text { Source: Statistical Office of the Republic of Serbia, Municipalities and Regions in the Republic of Serbia, for the } \\
\text { observed years. }\end{array}$ \\
*Data for Kosovo and Metohija region are not available.
\end{tabular}

Rural development policy reforms and necessary institutional adjustments are of particular importance in overcoming the transitional challenges for the Western Balkan countries, whose economies are highly dependent on agriculture (Martinovska Stojcheska et al., 2016). Observing the regions of the Republic of Serbia (one of the Western Balkan countries) according to the population density criterion below 150 inhabitants per $\mathrm{km}^{2}$ (Table 1), all regions except the Belgrade Region, could be considered as extremely rural. 
Thereby, the most important and often the only activity in countryside is agriculture. Therefore, regional and rural development policies are of particular importance to Serbia.

Serbia has a long tradition in dealing with the problems of regional development, but the policies related to the rural areas and irregularities of territorial development have not been sufficiently coherent. The place and role of rural development in balanced regional development have long been unjustly neglected. The economic development of rural areas should be based on the model of multifunctional agriculture and the introduction of additional activities, which will be the solution of employment outside agriculture in rural areas. Alternatives of employment in agriculture can be seen in activities connected to the agricultural production (food-processing industry, forest products and medicinal herbs, healthy food, etc.), tourism (rural, ecotourism, hunting, fishing, etc.), recreation, handicrafts, handwork, trade, culture, other service activities and similar. Apart from the decentralization and the adequate territorial organization of state on regions, it is necessary, to especially draw attention to detailed solving of the question of Serbian village and elimination of traditionally established dichotomy between village-town (Todorović et al., 2010).

Some factors can be generalized as having a key role in the increase in the scale of rural-urban linkages. Decreasing incomes from farming means that increasing numbers of rural residents engage in nonfarm activities that are often located in urban centres. The main reasons for the failure of many policies that try to use rural-urban links to promote regional development are that they were largely based on assumptions that did not necessarily reflect the real circumstances of certain locations and the people who live and work there. This requires a decentralized approach managed by local requirements, i.e. policies that support the positive aspects of rural-urban connections (Tacoli, 2013).

The world is in dire need of a new rural-urban compact, one that keeps delivering the food and fibres that the world needs, but at the same time is able to (Gutman, 2007): (a) improve jobs and income opportunities of rural population; (b) reduce rural - urban divide; (c) reverse the current trend of environmental degradation that is jeopardizing both people and nature.

\section{Methodology and data}

This paper analyses statistically significant differences between different groups of examined variables, using appropriate statistical tests. On the basis of territorial approach, what can be observed is a difference between the regions of Serbia according to the employment and unemployment, then share of imports and exports of regions in total imports and exports of the Serbia, as well as coverage of imports by exports, the share of regions in GDP, the investments in fixed assets for agriculture and total fixed capital formation, and the rate of absolute poverty. The secondary data for this survey are taken from the Statistical Office of the Republic of Serbia (Labour Force Survey, Foreign Trade in Goods, Statistical Yearbooks and Annual National Accounts, for the observed years) and 
from the Social Inclusion and Poverty Reduction Unit of the Government of the Republic of Serbia, 2018. Since integrated rural development and balanced regional development require adequate linking of agriculture with other economic activities, this paper analyses employment by regions, in the primary, secondary and tertiary sectors, i. e. linking agriculture with other economic activities. In terms of employment by regions, diversification of revenue generated in rural and urban areas has been observed. For these analyses, secondary data were also taken from the Statistical Office of the Republic of Serbia (Labour Force Survey and Household Budget Survey, for the observed years).

The analysis was conducted by examining differences between those regions, by territorial approach, for which the Kruskal-Wallis test was used. The Kruskal-Wallis test was used to first determine differences in employment between sectors within each region, and then to compare sectoral employment between regions. Also, it was the most suitable test to determine the sources of income that dominate within all rural areas of the regions of Serbia, as well as to compare those incomes between those rural areas of the region, to determine which incomes and in which areas are more dominant. The same comparison was made for the urban areas of Serbia in order to compare which incomes dominate in the rural areas of the region in relation to the urban ones.

\section{Empirical analysis and results}

This survey used the NUTS 2 classification for the Republic of Serbia, 2010, excluding Kosovo and Metohija, due to unavailability of data.

Table 2: Significant economic indicators of differences between regions of the Republic of Serbia, 2010-2017

\begin{tabular}{|c|c|c|c|c|c|c|c|c|c|}
\hline & 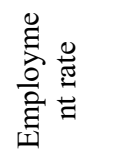 & 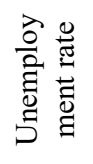 & 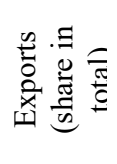 & 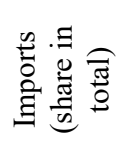 & 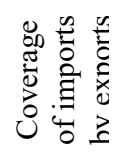 & 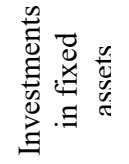 & 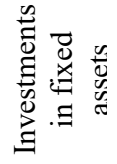 & 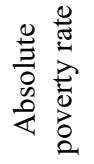 & 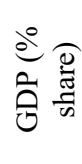 \\
\hline Chi Square & 9.69 & 3.39 & 24.98 & 29.09 & 25.64 & 28.91 & 18.36 & 25.98 & 29.11 \\
\hline AsumpSig. & $.021 * *$ & .335 & $.000^{*}$ & $.000^{*}$ & $.000 *$ & $.000 *$ & $.000^{*}$ & $.000^{*}$ & $.000^{*}$ \\
\hline \multicolumn{10}{|c|}{ Mean Rank } \\
\hline $\begin{array}{c}\text { Belgrade } \\
\text { Region }\end{array}$ & 21.13 & 12.31 & 16.25 & 28.50 & 4.50 & 28.50 & 10.06 & 4.63 & 28.5 \\
\hline $\begin{array}{c}\text { Vojvodina } \\
\text { Region }\end{array}$ & 12.06 & 17.56 & 28.19 & 20.50 & 12.75 & 20.38 & 28.50 & 16.00 & 20.5 \\
\hline $\begin{array}{l}\text { Šumadija and } \\
\text { Western } \\
\text { Serbia Region }\end{array}$ & 22.13 & 15.44 & 16.81 & 12.50 & 24.50 & 12.63 & 13.00 & 16.88 & 12.5 \\
\hline $\begin{array}{c}\text { Southern and } \\
\text { Eastern Serbia } \\
\text { Region }\end{array}$ & 10.69 & 20.69 & 4.75 & 4.50 & 24.25 & 4.50 & 14.44 & 28.50 & 4.5 \\
\hline
\end{tabular}


Based on Table 2, it is evident that Vojvodina has the highest share in exports, while the Belgrade Region in imports. On the other hand, Southern and Eastern Serbia participates the least in both imports and exports $(\mathrm{p}=.000)$, but it is second by the coverage of imports by exports, behind Šumadija and Western Serbia, while the Belgrade Region has the lowest coverage $(p=.000)$. In terms of investments in fixed assets, the Belgrade Region is the leader in comparison with others, while Southern and Eastern Serbia is in last place ( $p$ $=.000)$. It is in second place in terms of investments in fixed assets in agriculture, after the Region of Vojvodina, and the Belgrade Region is in last place $(\mathrm{p}=.000)$. The poorest is Southern and Eastern Serbia, then Šumadija and Western Serbia, Region of Vojvodina and finally the Belgrade Region $(\mathrm{p}=.000)$, which means that the rural regions are poorer. By share in the structure of GDP, the order is reverse $(p=.000)$, i. e. rural areas have lower GDP per capita than urban areas, which is an indicator of their lagging behind in economic development. The economic structure of rural areas is highly dependent on the primary sector, especially on agriculture, indicating a low diversification of income and population activities in these areas.

Based on the conducted analysis, it can be concluded that there is a statistically significant difference between the employment rate of the regions $(p=.021)$ and that the highest employment rate is in Šmadija and Western Serbia, followed by the Belgrade Region, Vojvodina and finally the Southern and Eastern Serbia region (Table 2). The unemployment rate is the lowest in the Belgrade Region and the highest in the Southern and Eastern Serbia region. These differences are not statistically significant, so the focus is on employment by region, both in agriculture and in other economic sectors. It also examines the revenue generated on this basis, both in rural and urban areas, within the observed regions.

Employed population, in addition to persons who work in an enterprise or organization, includes individual farmers, assisting household members, as well as persons who do some work independently. According to the Labour Law, employed workers are individuals employed by their employers. Table 3 shows that the most employed population is in the tertiary, secondary and finally in the primary sector, in all regions except Sumadija and Western Serbia $(p=.000)$ where the population is, after the tertiary sector, the most employed in the primary sector, so it opens the space for greater integration of agriculture with other economic activities, and for new jobs. Table 4 (shown in the Appendix) concludes that the most employed population in the primary sector are in Šmadija and Western Serbia, followed by Southern and Eastern Serbia, the Region of Vojvodina and finally the Belgrade Region $(\mathrm{p}=.000)$. In the secondary sector, the most population is employed in Vojvodina, then in Southern and Eastern Serbia, Šumadija and Western Serbia, while Belgrade Region is again at the back $(\mathrm{p}=.000)$, but in the first if tertiary sector is analysed, followed by Vojvodina, Southern and Eastern Serbia and finally Šmadija and Western Serbia $(\mathrm{p}=.000)$. 
Table 3: Employed population and workers, by regions and sectors of the Republic of Serbia, 2010-2017

\begin{tabular}{|c|c|c|c|c|c|}
\hline & & $\begin{array}{c}\text { Belgrade } \\
\text { Region }\end{array}$ & $\begin{array}{l}\text { Vojvodina } \\
\text { Region }\end{array}$ & $\begin{array}{c}\text { Šumadija } \\
\text { and Western } \\
\text { Serbia }\end{array}$ & $\begin{array}{c}\text { Southern } \\
\text { and } \\
\text { Eastern } \\
\text { Serbia }\end{array}$ \\
\hline \multirow{2}{*}{$\begin{array}{l}\text { Employed } \\
\text { population }\end{array}$} & Chi-Square & 20.480 & 20.489 & 15.585 & 20.489 \\
\hline & Asump Sig. & $.000 *$ & $.000 *$ & $.000 *$ & $.000 *$ \\
\hline \multirow{3}{*}{$\begin{array}{c}\text { Employed } \\
\text { workers }\end{array}$} & Chi-Square & 20.498 & 20.489 & 20.489 & 20.480 \\
\hline & Asump Sig. & $.000 *$ & $.000 *$ & $.000^{*}$ & $.000 *$ \\
\hline & Business sectors & \multicolumn{4}{|c|}{ Mean Rank } \\
\hline \multirow{3}{*}{$\begin{array}{l}\text { Employed } \\
\text { population }\end{array}$} & Primary & 4.50 & 4.50 & 9.31 & 4.50 \\
\hline & Secondary & 12.50 & 12.50 & 7.69 & 12.50 \\
\hline & Tertiary & 20.50 & 20.50 & 20.50 & 20.50 \\
\hline \multirow{3}{*}{$\begin{array}{l}\text { Employed } \\
\text { workers }\end{array}$} & Primary & 4.50 & 4.50 & 4.50 & 4.50 \\
\hline & Secondary & 12.50 & 12.50 & 12.50 & 12.50 \\
\hline & Tertiary & 20.50 & 20.50 & 20.50 & 20.50 \\
\hline
\end{tabular}

Note: The value is significant at $1 \%(*), 5 \%(*)$, and $10 \%\left({ }^{* * *}\right)$ confidence level.

Source: the authors' research, based on data of the Statistical Office of the Republic of Serbia, for the observed years

The most employed workers in the primary sector are in Vojvodina, Southern and Eastern Serbia, Šumadija and Western Serbia and finally in the Belgrade Region (Table 4). The highest number of registered workers working under the Employment Contract in primary sector is in Vojvodina, and the least in Šmadija and Western Serbia because this region is leading by employed population, but it is in third place by the number of employed workers in this sector. A similar situation is with the secondary sector, where the highest number of employees is in Šumadija and Western Serbia, then in Southern and Eastern Serbia, Vojvodina and finally in the Belgrade Region. Employed workers in the tertiary sector have the same structure as the employed population in terms of the regions with the highest and least employment of workers $(\mathrm{p}=.000)$.

Table 4: Significant differences between the regions of the Republic of Serbia in terms of employed population and workers in the primary, secondary and tertiary sectors, 2010-2017

\begin{tabular}{|c|c|c|c|c|c|c|}
\hline & \multicolumn{3}{|c|}{ Employed population } & \multicolumn{3}{|c|}{ Employed workers } \\
\hline & Primary & Secondary & Tertiary & Primary & Secondary & Tertiary \\
\hline Chi-Square & 27.429 & 22.984 & 22.253 & 26.555 & 28.107 & 21.213 \\
\hline Asump Sig. & $.000^{*}$ & $.000 *$ & $.000 *$ & $.000 *$ & $.000 *$ & $.000 *$ \\
\hline \multicolumn{7}{|c|}{ Mean Rank } \\
\hline $\begin{array}{l}\text { Belgrade } \\
\text { Region }\end{array}$ & 4.50 & 4.50 & 28.50 & 4.50 & 4.50 & 28.50 \\
\hline $\begin{array}{l}\text { Vojvodina } \\
\text { Region }\end{array}$ & 13.69 & 26.00 & 18.50 & 28.50 & 12.50 & 12.19 \\
\hline $\begin{array}{l}\text { Šumadija and } \\
\text { Western Serbia } \\
\text { Region }\end{array}$ & 28.38 & 15.00 & 4.88 & 15.13 & 27.75 & 8.13 \\
\hline
\end{tabular}




$\begin{aligned} & \text { Region of } 19.44 \\ & \text { and }\end{aligned}$
Southern 20.50
Eastern Serbia

Table 5 shows that regular salaries and pensions are dominant in rural areas of all regions. In the Belgrade Region, after the above, the highest share in income have other receipts and natural consumption $(\mathrm{p}=.000)$. In the Region of Vojvodina the highest share in the income, after the regular salaries and pensions, is taken up by income from agriculture, hunting and fishing and natural consumption. The situation is similar in Šumadija and Western Serbia and Southern and Eastern Serbia $(\mathrm{p}=.000)$, where natural consumption and income from agriculture, hunting and fishing are among the highest share of income.

Table 5: Sources of income in rural areas, by regions of the Republic of Serbia, 2011-2017

\begin{tabular}{|c|c|c|c|c|}
\hline & Belgrade region & $\begin{array}{l}\text { Region of } \\
\text { Vojvodina }\end{array}$ & $\begin{array}{c}\text { Region of } \\
\text { Šumadija and } \\
\text { Western Serbia }\end{array}$ & $\begin{array}{c}\text { Region of } \\
\text { Southern and } \\
\text { Eastern } \\
\text { Serbia } \\
\end{array}$ \\
\hline Chi-Square & 71.812 & 76.282 & 77.191 & 74.265 \\
\hline Asump Sig. & $.000 *$ & $.000^{*}$ & $.000 *$ & $.000 *$ \\
\hline \multicolumn{5}{|c|}{ Mean Rank } \\
\hline Regular salaries and wages & 77.00 & 77.00 & 77.00 & 70.36 \\
\hline Other income & 39.36 & 48.36 & 35.71 & 35.57 \\
\hline Pensions & 70.00 & 69.86 & 70.00 & 76.64 \\
\hline $\begin{array}{l}\text { Other social insurance } \\
\text { receipts }\end{array}$ & 43.64 & 41.14 & 41.21 & 38.00 \\
\hline $\begin{array}{l}\text { Income from agriculture, } \\
\text { hunting and fishing }\end{array}$ & 32.21 & 63.14 & 57.86 & 51.86 \\
\hline External receipts & 13.14 & 27.71 & 25.79 & 32.79 \\
\hline Real estate related income & 16.79 & 19.64 & 8.36 & 13.21 \\
\hline Donations and awards & 30.00 & 12.36 & 20.21 & 15.14 \\
\hline $\begin{array}{l}\text { Customer and investment } \\
\text { credits }\end{array}$ & 44.83 & 23.83 & 22.67 & 21.50 \\
\hline Other receipts & 61.21 & 33.86 & 48.93 & 51.14 \\
\hline Earned receipts in kind & 5.86 & 4.00 & 6.93 & 6.36 \\
\hline Natural consumption & 54.43 & 55.57 & 61.14 & 62.57 \\
\hline
\end{tabular}

Although agriculture is the dominant economic activity in rural areas of the Republic of Serbia, the share of agriculture in rural households' income is not dominant (Zekić et al., 2016, p. 172). In doing so, rural poverty is closely linked to the high 
dependency of the rural economy on agriculture. With this in mind, to stop the negative trends in rural areas, a more adequate rural development policy is needed, with the application of the concept of integrated rural development, as well as greater financial and overall institutional support for rural economy.

When looking at the rural population (Table 6), it is observed that the regular salaries and wages are the highest in the Belgrade Region, then Vojvodina, Sumadija and Western Serbia and finally in Southern and Eastern Serbia $(p=.000)$, while other income are the highest in Region of Vojvodina and the lowest in Šumadija and Western Serbia. The pensions have the highest importance in Southern and Eastern Serbia, and the lowest in the Region of Vojvodina $(\mathrm{p}=.000)$. The incomes from agriculture, hunting and fishing are the highest in the Region of Vojvodina (real estate related incomes are also high in Vojvodina), then in Sumadija and Western Serbia, Region of Southern and Eastern Serbia and finally in the Belgrade Region ( $\mathrm{p}=.000)$. External receipts dominate in Southern and Eastern Serbia, donations and awards in the Belgrade Region, and other receipts in the Southern and Eastern Serbia region. Natural consumption is the highest in Šumadija and Western Serbia, and the lowest in the Belgrade Region. In terms of individual consumption of household food and non-alcoholic beverages, although it dominates in all regions over other consumption categories it is not statistically significant between regions.

Table 6: Regional differences in rural areas of the Republic of Serbia in terms of sources of income and individual consumption of household, 2011-2017

\begin{tabular}{|c|c|c|c|c|c|c|c|c|c|c|c|c|c|}
\hline & 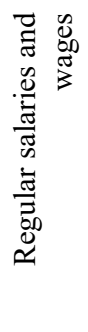 & 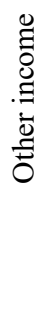 & $\begin{array}{c}n \\
.0 \\
\frac{0}{0} \\
0\end{array}$ & 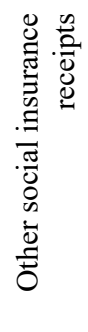 & 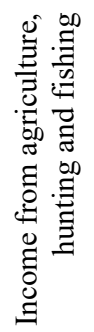 & 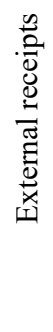 & 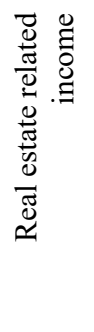 & 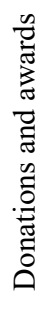 & 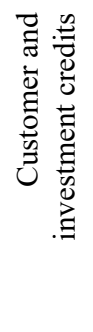 & 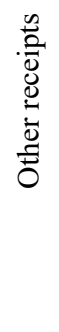 & 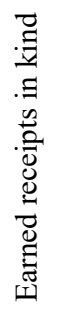 & 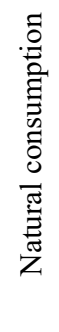 & 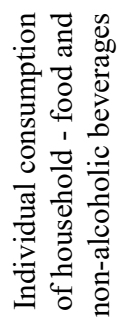 \\
\hline 光 & $\begin{array}{l}\text { ¿े } \\
\text { ते } \\
\text { ¿े }\end{array}$ & $\begin{array}{l}\stackrel{\Xi}{ \pm} \\
\pm\end{array}$ & $\frac{9}{9}$ & $\frac{a}{\grave{n}}$ & 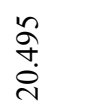 & $\begin{array}{l}\infty \\
\stackrel{\infty}{N} \\
\stackrel{N}{N}\end{array}$ & à & $\begin{array}{l}\infty \\
\infty \\
\infty \\
\qquad\end{array}$ & 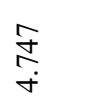 & $\frac{\text { P }}{n}$ & $\underset{\dot{\sigma}}{\vec{\sigma}}$ & $\begin{array}{l}\stackrel{0}{0} \\
\text { i } \\
\text { in }\end{array}$ & 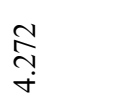 \\
\hline 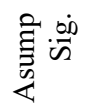 & $\stackrel{*}{8}$ & $\stackrel{*}{\stackrel{*}{\delta}}$ & * & $\begin{array}{l}\tilde{n} \\
n\end{array}$ & $\stackrel{*}{8} 8$ & $\stackrel{*}{*}$ & 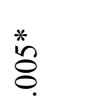 & $\frac{*}{8}$ & $\bar{a}$ & $\stackrel{*}{\stackrel{*}{8}}$ & @ి & * & $\stackrel{+}{\oplus}$ \\
\hline \multicolumn{14}{|c|}{ Mean Rank } \\
\hline 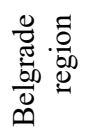 & 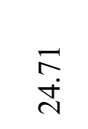 & $\stackrel{n}{=}$ & ñ & $\begin{array}{l}\vec{\sim} \\
\dot{J}\end{array}$ & $\underset{+}{\stackrel{+}{\circ}}$ & $\stackrel{\mathscr{\vartheta}}{\underset{\sim}{*}}$ & $\begin{array}{l}\stackrel{2}{n} \\
i n\end{array}$ & $\begin{array}{l}\mathbb{J} \\
\stackrel{d}{d}\end{array}$ & $\begin{array}{l}m \\
\infty \\
\sigma\end{array}$ & $\stackrel{\hat{\sigma}}{\circ}$ & $\begin{array}{l}\mathbb{0} \\
\stackrel{0}{0}\end{array}$ & 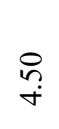 & $\stackrel{શ}{=}$ \\
\hline
\end{tabular}




\begin{tabular}{|c|c|c|c|c|c|c|c|c|c|c|c|c|c|}
\hline 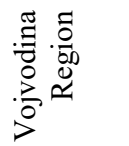 & $\underset{0}{\stackrel{0}{0}}$ & $\vec{\nabla}$ & $\underset{\sigma}{ \pm}$ & $\begin{array}{l}\mathbb{J} \\
\infty \\
\infty\end{array}$ & $\begin{array}{l}\text { ते } \\
\text { ते }\end{array}$ & $\frac{ \pm}{\stackrel{\oplus}{d}}$ & $\begin{array}{l}\infty \\
\infty \\
\stackrel{\sim}{\sim}\end{array}$ & तે & $\stackrel{m}{r}$ & $\begin{array}{l}\stackrel{0}{\sim} \\
\stackrel{\sim}{*}\end{array}$ & $\begin{array}{l}\vec{\sim} \\
\infty\end{array}$ & \begin{tabular}{l}
0 \\
$\stackrel{n}{0}$ \\
\hdashline
\end{tabular} & $\begin{array}{l}\text { ? } \\
\text { = }\end{array}$ \\
\hline 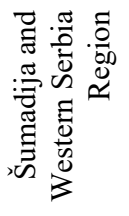 & $\begin{array}{l}\infty \\
\infty \\
ٍ\end{array}$ & $\underset{\infty}{\stackrel{\infty}{\infty}}$ & $\vec{a}$ & $\begin{array}{l}\stackrel{\vartheta}{0} \\
\stackrel{0}{0}\end{array}$ & సે & $\begin{array}{l}\Xi \\
\Xi\end{array}$ & $\hat{\sigma}$ & $\stackrel{\text { }}{\text { I }}$ & $\stackrel{m}{\sim}$ & $\begin{array}{l}\stackrel{m}{\sim} \\
\stackrel{n}{2}\end{array}$ & $\begin{array}{l}\hat{o} \\
\dot{\Xi}\end{array}$ & $\begin{array}{l}\text { ते } \\
\text { ते }\end{array}$ & $\begin{array}{l}\text { กิ } \\
\text { in }\end{array}$ \\
\hline 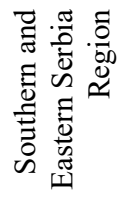 & $\begin{array}{l}\stackrel{9}{+} \\
\stackrel{1}{*}\end{array}$ & $\begin{array}{l}\stackrel{\vartheta}{\stackrel{ \pm}{ \pm}} \\
\text { }\end{array}$ & $\begin{array}{l}\stackrel{2}{N} \\
\stackrel{N}{N}\end{array}$ & $\begin{array}{l}\mathscr{0} \\
\stackrel{\sim}{ \pm}\end{array}$ & 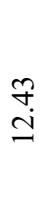 & $\begin{array}{l}\text { ते } \\
\text { ते }\end{array}$ & 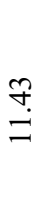 & $\hat{0}$ & 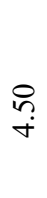 & $\stackrel{\Xi}{\stackrel{\Xi}{2}}$ & $\begin{array}{l}5 \\
\text { in }\end{array}$ & $\vec{\partial}$ & 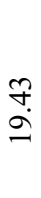 \\
\hline
\end{tabular}

Note: The value is significant at $1 \%(*), 5 \%\left(^{*}\right)$, and $10 \%(* * *)$ confidence level.

Source: the authors' research, based on data of the Statistical Office of the Republic of Serbia, for the observed year

Observing the urban areas of analysed regions (Table 7), it is noted that regular salaries and wages and pensions dominate. In the Belgrade Region other income and other receipts also have a significant share, while in Vojvodina, in addition to other incomes and social insurance receipts, income from agriculture, hunting and fishing are also significant. In urban areas in Šumadija and Western Serbia incomes from agriculture, hunting and fishing are among the smallest, as well as in Southern and Eastern Serbia $(\mathrm{p}=.000)$. Otherwise, in the urban areas of the regions of Serbia income from agriculture, hunting and fishing has the highest importance in Vojvodina, although they are less important than in rural areas.

Table 7: Sources of income in urban areas, by regions of the Republic of Serbia, 2011-2017

\begin{tabular}{lcccc}
\hline & Belgrade Region & $\begin{array}{c}\text { Vojvodina } \\
\text { Region }\end{array}$ & $\begin{array}{c}\text { Sumadija and } \\
\text { Western Serbia } \\
\text { Region }\end{array}$ & $\begin{array}{c}\text { Southern and } \\
\text { Eastern Serbia } \\
\text { Region }\end{array}$ \\
\hline Chi-Square & 73.185 & 68.740 & 70.678 & 74.491 \\
\hline Asump Sig. & $.000^{*}$ & $.000^{*}$ & $.000^{*}$ & $.000^{*}$ \\
\hline Regular salaries and wages & 77.00 & 77.00 & 77.00 & 77.00 \\
\hline Other income & 59.00 & 58.79 & 45.86 & 53.36 \\
\hline Pensions & 70.00 & 70.00 & 70.00 & 70.00 \\
\hline Social insurance receipts & 48.50 & 51.57 & 56.57 & 53.71 \\
\hline $\begin{array}{l}\text { Income from agriculture, hunting } \\
\text { and fishing }\end{array}$ & 8.14 & 49.43 & 32.21 & 12.71 \\
\hline
\end{tabular}




\begin{tabular}{lllll}
\hline External receipts & 31.71 & 32.64 & 32.71 & 40.86 \\
\hline Real estate related income & 28.14 & 19.86 & 12.79 & 19.21 \\
\hline Donations and awards & 44.47 & 15.64 & 28.93 & 28.93 \\
\hline Customer and investment credits & 39.83 & 41.83 & 48.67 & 24.00 \\
\hline Other receipts & 53.43 & 34.93 & 57.71 & 60.43 \\
\hline Earned receipts in kind & 10.71 & 4.00 & 4.00 & 30.93 \\
\hline Natural consumption & 14.57 & 31.07 & 24.21 & Note: The value is significant at 1\% $\left(^{*}\right), 5 \%\left(^{*}\right)$, and $10 \%\left(^{* * *}\right)$ confidence level. \\
\hline \multicolumn{4}{r}{ Source: the authors' research, based on data of the Statistical Office of the Republic of Serbia, for the observed } \\
years.
\end{tabular}

Revenues that are statistically significant and that differ by regions in urban areas (Table 8) are other receipts. They are the highest in Southern and Eastern Serbia and the smallest in the Region of Vojvodina. Income from agriculture, hunting and fishing are the highest in Vojvodina, followed by Šumadija and Western Serbia, Southern and Eastern Serbia, and finally the Belgrade Region. External receipts are the highest in Vojvodina and the lowest in the Belgrade Region. Also, Vojvodina is dominated by real estate related income over other regions, while donations and awards are the most significant for the Belgrade Region. Customer and investment credits are highest in Šumadija and Western Serbia, other receipts in Southern and Eastern Serbia, while natural consumption is highest in Vojvodina and the lowest in the Belgrade Region. In terms of individual consumption of household, urban and rural areas are dominated by food and non-alcoholic beverages, with no statistically significant difference between regions. Income from agriculture, hunting and fishing have the largest share in Vojvodina, then in Šumadija and Western Serbia, Southern and Eastern Serbia, and the least importance is in the Belgrade Region.

Table 8: Regional differences in urban areas of the Republic of Serbia in terms of sources of income and individual consumption of household, 2011-2017

\begin{tabular}{|c|c|c|c|c|c|c|c|c|c|c|c|c|c|}
\hline & 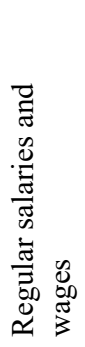 & 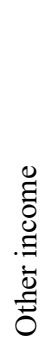 & 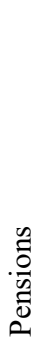 & 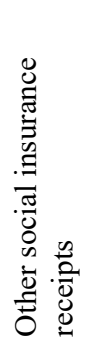 & 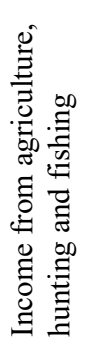 & 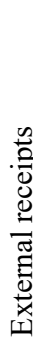 & 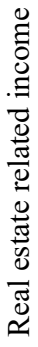 & 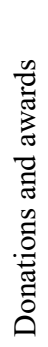 & 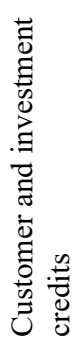 & 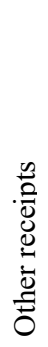 & 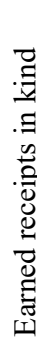 & 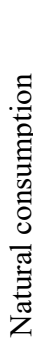 & 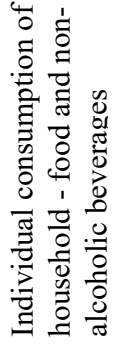 \\
\hline Chi-Square & $\underset{\stackrel{?}{+}}{\stackrel{?}{+}}$ & $\begin{array}{l}b \\
? \\
? \\
? \\
?\end{array}$ & $\begin{array}{l}8 \\
\text { ? } \\
?\end{array}$ & $\underset{\nabla}{\sigma}$ & $\begin{array}{l}n \\
\text { ñ } \\
\stackrel{n}{v}\end{array}$ & $\frac{N}{\stackrel{\infty}{\sim}}$ & $\begin{array}{l}\mathscr{n} \\
\stackrel{\infty}{N} \\
i\end{array}$ & $\frac{n}{\nabla}$ & 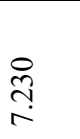 & $\frac{a}{0}$ & 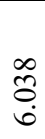 & 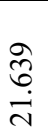 & 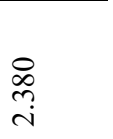 \\
\hline Asump Sig. & $\begin{array}{l}\text { Dे } \\
\text { ஸे }\end{array}$ & 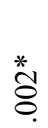 & ָे & $\stackrel{\infty}{\Omega}$ & $\stackrel{*}{\text { }} 8$ & $\stackrel{*}{\text { \& }}$ & $\stackrel{N}{?}$ & 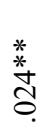 & 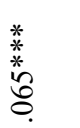 & $\frac{*}{8}$ & $\stackrel{0}{=}$ & $\stackrel{*}{*} 8$ & $\hat{\operatorname{a}}$ \\
\hline
\end{tabular}




\begin{tabular}{|c|c|c|c|c|c|c|c|c|c|c|c|c|c|}
\hline Belgrade region & ते & $\begin{array}{l}\hat{o} \\
\stackrel{+}{ \pm}\end{array}$ & $\stackrel{2}{\rightleftharpoons}$ & $\begin{array}{l}\triangleright \\
\infty \\
\infty\end{array}$ & $\begin{array}{l}\infty \\
\infty \\
i\end{array}$ & in & $\underset{0}{8}$ & $\begin{array}{l}\hat{o} \\
\text { ì }\end{array}$ & mु? & $\overrightarrow{\tilde{y}}$ & $\underset{\substack{\mathscr{\infty} \\
\infty}}{\sim}$ & $\underset{+}{\stackrel{8}{ }}$ & $\stackrel{i n}{n}$ \\
\hline Region of Vojvodina & $\begin{array}{l}\dot{J} \\
\stackrel{0}{0}\end{array}$ & $\underset{\vec{d}}{\stackrel{\Delta}{\sim}}$ & 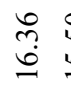 & $\begin{array}{l}i \\
n \\
n\end{array}$ & $\begin{array}{l}\text { } \\
\stackrel{+}{+}\end{array}$ & ㅇ. & సે & $\vec{a}$ & $\begin{array}{l}\hat{b} \\
\infty\end{array}$ & $\begin{array}{l}\text { in } \\
\text { in }\end{array}$ & 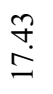 & $\hat{\tilde{\nu}}$ & 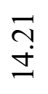 \\
\hline $\begin{array}{l}\text { Šumadija and Western } \\
\text { Serbia Region }\end{array}$ & ị & ì & $\vec{ָ}$ & $\underset{0}{8}$ & $\begin{array}{l}\infty \\
\infty \\
\end{array}$ & $\stackrel{\infty}{\infty}$ & $\ddot{a}$ & $\begin{array}{l}8 \\
\stackrel{+}{\Xi}\end{array}$ & $\begin{array}{l}8 \\
0\end{array}$ & $\stackrel{?}{\stackrel{\vartheta}{b}}$ & $\underline{0}$ & $\stackrel{ \pm}{\stackrel{\Xi}{\sim}}$ & 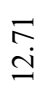 \\
\hline $\begin{array}{l}\text { Southern and Eastern } \\
\text { Serbia Region }\end{array}$ & $\begin{array}{l}\infty \\
\infty \\
\stackrel{\sim}{\sim}\end{array}$ & $\stackrel{\vec{N}}{\underline{\Xi}}$ & $\begin{array}{ll}\dot{\sigma} & 5 \\
\dot{2} & 5\end{array}$ & $\begin{array}{l}\text { J̦ } \\
\stackrel{1}{-}\end{array}$ & $\overrightarrow{\widetilde{o}}$ & $\stackrel{\circ}{\mathfrak{n}}$ & $\begin{array}{l}8 \\
\ddot{2}\end{array}$ & $\stackrel{\vec{N}}{i}$ & $\underset{\sim}{\stackrel{\leftrightarrow}{i}}$ & $\begin{array}{l}8 \\
\ddot{\lambda}\end{array}$ & $\hat{\Xi}$ & $\hat{\sigma}$ & $\begin{array}{l}0 \\
n \\
\infty\end{array}$ \\
\hline
\end{tabular}

Note: The value is significant at $1 \%(*), 5 \%\left(^{*}\right)$, and $10 \%(* * *)$ confidence level.

Source: Authors' research, based on data of the Statistical Office of the Republic of Serbia, for the observed years.

Natural consumption, as an essential component of rural income, which is not the case in urban areas, also differs between the regions. In rural areas it is most significant for the Šumadija and Western Serbia, then Southern and Eastern Serbia, Vojvodina and finally the Belgrade Region (Table 6). In urban areas it is of greatest importance for the Region of Vojvodina and Southern and Eastern Serbia, while it is less important for Sumadija and Western Serbia and the Belgrade Region (Table 8).

\section{Conclusion}

It is observed that unemployment in the Belgrade Region, as well as the absolute poverty rate in this region, are lower than in the extremely rural regions (Vojvodina, Sumadija and Western Serbia, Southern and Eastern Serbia). Thereby, the Belgrade Region has the lowest export-import ratio, but its share in GDP is the highest. It also has the smallest investment in agriculture, but the highest total investment in fixed assets. In all observed regions of the Republic of Serbia, the highest employment is in the tertiary sector. In rural areas, employment in the primary sector as well as in the secondary sector is very important, while employment in the tertiary sector is of particular importance in the Belgrade Region. The above points to the conclusion that all rural areas should focus more on linking the primary sector with the tertiary, but also with the secondary, through the development of non-agricultural activities, primarily rural tourism, industrial processing of primary agricultural products, etc.

Although higher employment in the primary sector is in rural than in non-rural regions of the Republic of Serbia, and since higher incomes from agriculture are generated in rural regions, particularly in Vojvodina. These incomes are in all regions of the Republic of Serbia behind regular salaries and wages, which are the highest in the Belgrade Region, as well as behind pension income. The above points out that in Vojvodina, Šumadija and 
Western Serbia, as well as in Southern and Eastern Serbia the importance of primary sector, should be increased. The importance of income generated on this basis should increase through the affirmation of a modern approach to agriculture and occupation farmer. This could reduce the poverty rate in these regions, while increase employment.

Looking at urban areas by regions, regular salaries and wages and pensions are the dominant sources of income. Income from agriculture, hunting and fishing has no statistical significance in the urban areas of the observed regions, except in Vojvodina, where they are still very significant, but less than in rural areas.

Generally speaking, linking agriculture with the tertiary sector through the development of rural tourism, as well as with the secondary sector through the development of small and medium-sized enterprises in the processing of primary agricultural products, could be best achieved in the Vojvodina, then Sumadija and Western Serbia and also the Southern and Eastern Serbia. In the Belgrade Region the development of agriculture and its strong integration with other sectors would not have significance and extraordinary success, given that it is an urban region and that the primary sector, as well as agricultural revenues are lower than in other regions. Thereby, the experience of the Republic of Serbia could be useful for others.

The basic hypothesis of this paper is confirmed for all regions except Belgrade, which means that in extremely rural regions, i.e. in those regions where the primary sector is significant, it is extremely important to encourage integrated rural development concept.

Since in all regions there is a higher employment in the tertiary and secondary sectors in relation to the primary sector, and agriculture is the dominant economic activity in rural areas, i.e. extremely rural regions of the Republic of Serbia, they should be based on the differentiation of employment, i.e. develop the secondary sector, through the processing industry in rural areas, as well as the tertiary sector, through rural tourism. On the basis of such employment, more non-agricultural income would be generated. Given that these incomes dominate in rural as well as urban areas, this would reduce the difference in relation to urban areas.

Raising the capacity of the poor to participate in the better-paid types of rural nonfarm employment (RNFE) is crucial - via employment skills training, education, infrastructure, credit, etc. RNFE has grown fastest and been most poverty-alleviating where there are dynamic growth motors, in particular in the agricultural sector, but also in tourism, links to urban areas, mining and forestry (Reardon et al., 2001).

The Belgrade Region in relation to other highly rural regions in Serbia dominates in terms of employment in the tertiary sector, while rural regions are more dominant in terms of primary and secondary sector, so in these regions it is necessary to develop processing capacities of agricultural products and connect agriculture with industry and tertiary sector (through rural tourism, delivery of produced organic products, handicrafts and other sights of rural areas). 
Emphasis needs to be on the importance of designing a development strategy that links agriculture and other sectors. Over the longer term, thriving industrial and service sectors are required so as to sustain the dynamism of the whole economy and achieve the eradication of rural and urban poverty. Agriculture has inherent limitations as an engine for growth over the longer term while industry has a greater potential to generate technological innovations. Services play an increasingly vital part in the generation of innovations as well as in the diffusion of knowledge and information which will raise productivity in agriculture and industry. Services can also provide a bridge between agriculture and industry (Kay, 2009).

Programmes for rural development should aim to enhance the contribution of both agricultural and non-agricultural sectors to poverty alleviation by strengthening linkages between the sectors (Makhura, 2001). This is especially important because all rural areas are dominated by income from employment, as well as pensions (acquired on the basis of length of employment), although agriculture is the dominant economic activity in these areas. Therefore, the population of these areas should have jobs on the basis of which they will earn that income, and these jobs can be created in these areas by developing industry (processing facilities for agricultural products), as well as developing rural tourism and agencies by local governments that will promote these areas in the country and the world.

Rural development is a multidimensional phenomenon. Local government is often the centrepiece of rural political systems. Interventions to reconfigure local government are therefore quintessentially rural development initiatives (Douglas, 2005). Non-farm incomes dominate in urban areas, which is additional reason for their support in rural areas, too, in order to minimize the gap between these areas.

Rural-urban linkages play a crucial role in the generation of income, employment and wealth. It should be noted that many people in rural areas engage in urban activities, such as manufacturing and service provision and, likewise, many people in urban areas engage in agricultural production, either for household consumption or for sale or both. The rural and urban economies are therefore interdependent and complementary. Rural and urban development must be brought together in the planning process and an attention should be given to the decentralization of government. Stronger rural-urban linkages could play a crucial role in poverty reduction and sustainable development in developing countries (Akkoyunlu, 2015).

As revenues from agriculture are more pronounced in rural areas than in urban areas, the development of other sectors in rural areas should be done in cohesion and connection with the agricultural sector, adoption of relevant strategy and involvement of the local governments. 


\section{References}

Akkoyunlu, S. (2015). The potential of rural-urban linkages for sustainable development and trade. International Journal of Sustainable Development \& World Policy, 4(2), 20-40. Doi: https://doi.org/10.18488/JOURNAL.26/2015.4.2/26.2.20.40

Amekawa, Y. (2011). Agroecology and sustainable livelihoods: towards an integrated approach to rural development. Journal of Sustainable Agriculture, 35(2), 118-162. Doi: https://doi.org/10.1080/10440046.2011.539124.

Bański, J. (2018). The future of rural Poland: the main trends and possible scenario. Eastern European Countryside, 23(1), 71-102. Doi: https://doi.org/10.1515/eec-2017-0004.

De Janvry, A., \& Sadoulet, E. (2005). Achieving success in rural development: toward implementation of an integral approach. Agricultural Economics, 32, 75-89. Doi: https://doi.org/10.1111/j.0169-5150.2004.00015.x.

Douglas, D. (2005). The restructuring of local government in rural regions: a rural development perspective. Journal of Rural Studies, 21(2), 231-246. Doi: https://doi.org/10.1016/j.jrurstud.2005.01.003.

Gutman, P. (2007). Ecosystem services: Foundations for a new rural-urban compact. Ecological Economics, 62(3-4), 383-387. Doi: https://doi.org/10.1016/j.ecolecon.2007.02.027.

Kay, C. (2009). Development strategies and rural development: exploring synergies, eradicating poverty. The Journal of Peasant Studies, 36(1), 103-137. Doi: https://doi.org/10.1080/03066150902820339

Kilkenny, M. (2010). Urban/regional economics and rural development. Journal of Regional Science, 50(1), 449-470. Doi: https://doi.org/10.1111/j.1467-9787.2009.00661.x.

Knickel, K., \& Renting, H. (2000). Methodological and conceptual issues in the study of multifunctionality and rural development. Sociologia Ruralis, 40(4), 512-528. Doi: https://doi.org/10.1111/1467-9523.00164.

Kvrgić, G., \& Ristić, L. (2018). Unutrašnj izazovi održivog razvoja ruralnih područja Republike Srbije. Naučne publikacije državnog Univerziteta u Novom Pazaru, Serija B: Društvene \& humanističke nauke, 1(1), 28-46.

Leupolt, M. (1977). Integrated rural development: key elements of an integrated rural development strategy. Sociologia Ruralis, 17(1), 7-28. Doi: https://doi.org/10.1111/j.14679523.1977.tb00849.x.

Makhura, M. (2001). Patterns of relationships between farm and nonfarm sources of income in the rural areas of the Northern Province. Agrekon: Agricultural Economics Research, Policy and Practice in Southern Africa, 40(2), 259-268. Doi: https://doi.org/10.1080/03031853.2001.9524949. 
Martinovska Stojcheska, A., Kotevska, A., Bogdanov, N., \& Nikolić, A. (2016). How do farmers respond to rural development policy challenges? Evidence from Macedonia, Serbia and Bosnia and Herzegovina. Land Use Policy, 59, 71-83. Doi: https://doi.org/10.1016/j.landusepol.2016.08.019.

OECD. (2011). OECD regional typology. Retrieved October 10, 2019, from https:/www.oecd.org/cfe/regionalpolicy/OECD_regional_typology_Nov2012.pdf

Pawlak, K., Kołodziejczak, M., \& Xie, Y. (2019). Horizontal integration in the agricultural sector as a factor increasing its competitiveness - experience from Poland. Eastern European Countryside, 25(1), 195-232. Doi: https://doi.org/10.12775/eec.2019.008.

Pejanović, R., Glavaš-Trbić, D., \& Tomaš-Simin, M. (2017). Problems of agricultural and rural development in Serbia and necessity of new agricultural policy. Economics of Agriculture, 64(4), 1619-1633. Doi: https://doi.org/10.5937/ekoPolj1704619P.

Perger, E. (2016). Local responses to the structural changes of national development policy in Hungarian rural regions. Eastern European Countryside, 22(1), 69-83. Doi: https://doi.org/10.1515/eec-2016-0004.

Ploeg, J.D. van der, Renting, H., Brunori, G., Knickel, K., Mannion, J., Marsden, T., de Roest, K., Sevilla-Guzmán, E. \& Ventura, F. (2000). Rural development: from practices and policies towards theory. Sociologia Ruralis, 40(4), 391-408. Doi: https://doi.org/10.1111/1467-9523.00156.

Reardon, T., Berdegué, J., \& Escobar, G. (2001). Rural nonfarm employment and incomes in Latin America: overview and policy implications. World Development, 29(3), 395-409. Doi: https://doi.org/10.1016/S0305-750X(00)00112-1.

Reardon, T., Stamoulis, K., \& Pingali, P. (2007). Rural nonfarm employment in developing countries in an era of globalization. Agricultural Economics, 37, 173-183. Doi: https://doi.org/10.1111/j.1574-0862.2007.00243.x.

Rikalović, G., Molnar, D., \& Mikić, H. (2017). Regionalizacija Srbije i EU fondovi. Acta economica, 15(26), 199-220. Doi: https://doi.org/10.7251/ACE1726199R

Ristić, L. (2013). Strategijsko upravljanje održivim ruralnim razvojem u Republici Srbiji. Ekonomski horizonti, 15(3), 229-243. Doi: https://doi.org/10.5937/ekonhor1303229R

Statistical Office of the Republic of Serbia. (2010-2017). Publications. Retrieved October 10, 2019, from https://www.stat.gov.rs/.

Tacoli, C. (2013). The links between urban and rural development. Environment \& Urbanization, 15(1), 3-12. Doi: https://doi.org/10.1177/095624780301500111 
Todorović, M., Drobnjaković, M., \& Gligić-Simeunović, A. (2010). Specifics of rural areas of Serbia from the aspects of regional development. Economics of Agriculture, 57(2), 605612.

Woods, M., \& McDonagh, J. (2011). Rural Europe and the world: globalization and rural development (Editorial). European Countryside, 3(3), 153-163. Doi: https://doi.org/10.2478/v10091-012-0001-z.

Zekić, S., Matkovski, B., \& Kleut, Ž. (2016). IPARD fondovi u funkciji razvoja ruralnih područja Republike Srbije. Ekonomski horizonti, 18(2), 169-180. Doi: https://doi.org/10.5937/ekonhor1602169Z 